One Ring to Revascularize Them All: Assessing The End Results of

\title{
Coronary Bioresorbable Vascular Scaffolds as Revascularization
}

\section{Approach for Chronic Total Occlusions}

Prima Hapsari Wulandari ${ }^{1 *}$

${ }^{1}$ Affiliation - Faculty of Medicine, Airlangga University, Indonesia

*Corresponding email: Prima Hapsari Wulandari. Mailing address. Email:

primahapsari@outlook.com 


\begin{abstract}
Following the era of percutaneous coronary intervention (PCI), the occurrence of revascularization in chronic total occlusions (CTO) is correlated with positive and longstanding echocardiographic and clinical outcomes. The beneficial outcomes of bioresorbable vascular scaffolds (BVS) treatment to manage CTO are currently inconclusive, since patients presenting with CTO were frequently ruled out from a vast number of randomized clinical trials (RCTs) which assess BVS. This systematic review is aimed to review and recapitulate available reports on the clinical outcomes of CTO with BVS treatment. Available data in the Cochrane Library, EMBASE, MEDLINE, and, clinicaltrials.gov are being examined to gather investigations on BVS-treated CTO. Outcomes of concern involved vessel restenosis, scaffold thrombosis, target lesion revascularization, myocardial infarction, major adverse cardiac events (MACE), and allcause mortality. Thirteen papers have met the criteria for inclusion. All papers were written based on observational studies cumulative population samples of 1,077 . Two papers were found to involve retrospective comparison of drug-eluting stents (DES) group with BVS group. The investigations had varying group size and duration of follow-up. This review presented beneficial results for BVS-treated CTO. In double-arm studies, the recorded MACE incidence diverged from $0 \%$ to $6.7 \%$ with no notable differences between DES and BVS populations. While reports on the implantation of the first-generation BVS in CTO populations are infrequent and recruited only insufficient observational studies samples, the available data is promising. The data shows satisfactory results which are analogous to second-generation DES. However, additional investigation by means of RCTs and the application of more novel scaffolds is necessitated.
\end{abstract}

Keywords: chronic total occlusion, percutaneous coronary intervention, bioresorbable vascular scaffold, drug eluting stent, coronary artery disease 


\section{INTRODUCTION}

In coronary artery diseases, the condition of chronic total occlusion (CTO) is described as a fully occluded vessel with thrombolysis in myocardial infarction (TIMI) patients, with a grade of flow 0 and persisting for longer than three months [1]. CTOs exist in roughly $20 \%$ of individuals who are receiving elective angiography due to coronary artery disease [2]. CTO revascularization approach by percutaneous coronary intervention (PCI) is correlated with a relief of chest pain (angina), moderation in infarct expansion of the myocardium, better function of the left ventricular, smaller probability for the need of future coronary artery bypass grafting, and greater patients survival despite existing manifestation of collateral circulation [35]. However, since the use of multiple, consecutive, and extended stents (known as the vessel caging) are usually needed to administer a vessel with CTO, the vessel is predisposed to hazards of delayed restenosis and stent thrombosis [6-8]. A substitute choice for treatment is offered by the bioresorbable vascular scaffolds (BVS). The novel characteristics of BVS enable them to advance the healing process of vessel, facilitating for the remodelling of the vascular system, preventing delayed lumen enlargement, and reviving the normal vasomotion. All these effects result in escaping the issues of vessel caging and the hazard of delayed thrombosis [9, 10]. The beneficial outcomes derived from incorporating bioresorbable vascular scaffolds (BVS) to manage CTO are currently inconclusive since patients presenting with CTO were frequently ruled out from a vast number of randomized clinical trials (RCTs) assessing BVS. This systematic review is aimed to compile available reports on the clinical outcomes of CTO with BVS treatment.

\section{REVIEW}

\section{Materials and methods}

This review followed the Preferred Reporting Items for Systematic Reviews and MetaAnalyses (PRISMA) guidelines [11]. Systematic electronic searches were implemented in the Cochrane library, EMBASE, MEDLINE, and clinicaltrials.gov for systematic reviews, observational studies, case series, and clinical trials on Abbott Vascular's Absorb bioresorbable vascular scaffolds in patients presenting with chronic total occlusions. Extensive search keywords were incorporated: "chronic total occlusion" and "bioresorbable vascular scaffold". These keywords were consolidated employing the Boolean operator. Furthermore, to gather supplementary references, additional publications were sought from the chosen papers and papers that cited the chosen investigations. 
Studies were chosen to review once they satisfied the following criteria of inclusion: patients with age of equal to or more than 18 years; chronic total occlusion (CTO) manifestations of one or more coronary arteries; incorporating bioresorbable vascular scaffolds implantation; disclosed a minimum of one efficacy and safety outcomes: vessel restenosis, stent or scaffold thrombosis (ST), target lesion revascularization (TLR), myocardial infarction (MI), major adverse cardiac events (MACE), cardiac death, and all-cause mortality; having a minimum of three months of patients follow-up.

Exclusion criteria for studies elimination were: investigations using a language other than English; case series and case reports having fewer than ten samples; investigations recruiting subjects other than human. The collection of papers for fitness of criteria and data harvesting was performed by PHW. Selected evidence included study design, study type, publication year, clinical and demographic features, primary and secondary outcomes, and follow-up duration. Selected outcomes were successful procedure approach, ST, TLR, target vessel revascularization (TVR), MI, MACE, and deaths by non-cardiac and cardiac causes. Outcomes were recorded quantitatively and published as the total study population percentages. On account of the heterogeneity of study design among the included investigations, meta-analysis of evidence was not conducted. Selected papers were assessed for possible biases utilizing the Cochrane risk of bias assessment tool (ROBINS-I).

\section{Results}

Applying the strategy for evidence search as outlined, we distinguished potential data, and 95 identical papers were spotted and eliminated. The remaining papers were filtered. Papers using a language other than English, editorials, review articles, conference abstracts, case series and case reports having fewer than ten samples were further eliminated. A sum of thirteen papers fulfilled the criteria of inclusion for investigation.

\section{Features of Selected Studies}

All investigations selected were observational study. A total of 1,077 patients were included, having a median size of the population of 41, with interquartile range (IQR) of 29.5 to 67.5 individuals. The median follow-up period was 3.3 months to 23.5 months. Male patients were dominant in the population (77.5\% to $98 \%$ ), comprising a mean age of 56.9 years to 65.7 years. Of 13 papers selected, 11 were retrospective cohort investigations, and therefore did not constitute a control population. The remaining two were double-arm investigations which constituted comparator populations which retrospectively contrasted drug-eluting stents (DES) with BVS. All investigations described the term CTO identically as a complete vessel occlusion with TIMI flow of zero for longer than three months period. The primary and secondary 
outcomes differ moderately from one investigation to another, as seen in Table 1. However, they were primarily concentrated on the effect of combination or individual impact of major adverse cardiovascular events such as ischemia-driven target lesion revascularization, myocardial infarction, and cardiac death.

Table 1. A comparison table of clinical studies which investigated the primary and secondary outcomes of Bioresorbable Vascular Scaffolds and Drug-Eluting Stents

$\begin{array}{ccccc}\text { No. Author } \quad \text { Year } & \begin{array}{c}\text { Type and } \\ \text { Design }\end{array} & \begin{array}{c}\text { Population, } \\ \text { Follow-up } \\ \end{array} & \text { Primary Outcomes } & \text { Secondary } \\ & & \text { Duration } & \text { Outcomes }\end{array}$

$\begin{array}{lllll}\text { 1. La Manna et } 2018 & \text { Prospective } & \text { N=21. Median } \\ \text { al. [12] } & \text { single center } & \text { of } 447 \text { days } & \begin{array}{l}\text { One-year outcomes } \\ \text { of optical coherence }\end{array} & \text { MACE at one year is } \\ & \text { series (sub- } & \text { (IQR 365 to } & \text { tomography } & \text { compound of TLR, } \\ & \text { study } & 713 \text { days) } & & \text { MI, and death } \\ & \text { GHOST- } & & \\ \text { CTO) } & & \end{array}$

\begin{tabular}{lllll}
\hline 2. $\begin{array}{llll}\text { Mitomo et } \\
\text { al. [13] }\end{array}$ & Retrospective & $\mathrm{N}=65$. Median & Target lesion failure & Scaffold thrombosis, \\
& international & of 453 days & is described as a & clinically driven \\
& multi-center & compound of & target vessel \\
& registry & clinically driven & revascularization, \\
& & TLR, target vessel & and all-cause \\
& & MI, and cardiac death & mortality
\end{tabular}

$\begin{array}{llllll}\text { 3. Maeremans } & 2017 & \text { Prospective } & \mathrm{N}=41 \text {. Twelve } & \text { TVF incidence (in- } & \text { BVS patency and } \\ \text { et al. [14] } & \text { multi-center } & \text { months follow- } & \text { stent re-stenosis or } & \text { performance of } \\ & \text { single arm } & \text { up } & \text { occlusion with or } & \text { quantitative MSCT } \\ & \text { study } & & \text { without TVR) } & \text { imaging to assess } \\ & & & & \text { area and diameter of } \\ & & & \text { stenosis at one-year } \\ & & & \text { follow-up }\end{array}$

$\begin{array}{lllll}\text { 4. Kugler et al. } 2017 & \text { Retrospective } & \text { BVS (n=14 } & \text { Compound of target } & \text { None } \\ & \text { single center } & \text { with 15 CTO); } & \text { lesion } \\ & \text { study, two- } & \text { DES (n=15). } & \text { revascularization, MI } \\ & \text { arms, BVS } & \text { Angiographic } & \text { not clearly related to } \\ & \text { compared } & \text { follow-up at } & \text { a nontarget vessel, } \\ \end{array}$




\begin{tabular}{|c|c|c|c|c|c|c|}
\hline & & & $\begin{array}{l}\text { with DES } \\
\text { (Ulm-CSI } \\
\text { CTO) }\end{array}$ & $\begin{array}{l}\text { nine month in } \\
96.7 \% \text {. Clinical } \\
\text { follow-up at } \\
\text { twelve months } \\
\text { in all patients }\end{array}$ & and cardiac death & \\
\hline 5. & $\begin{array}{l}\text { Fam et al. } \\
{[6]}\end{array}$ & 2017 & $\begin{array}{l}\text { Prospective } \\
\text { multi-center } \\
\text { single-arm } \\
\text { registry }\end{array}$ & $\begin{array}{l}\mathrm{N}=105 . \text { Six } \\
\text { months follow- } \\
\text { up }\end{array}$ & $\begin{array}{l}\text { Scaffold thrombosis, } \\
\text { clinical TLR, non- } \\
\text { TLR, MI, cardiac } \\
\text { death }\end{array}$ & None \\
\hline 6. & $\begin{array}{l}\text { Yamaç } \\
\text { et al [16] }\end{array}$ & 2016 & $\begin{array}{l}\text { Prospective } \\
\text { single-center } \\
\text { single-arm } \\
\text { study }\end{array}$ & $\begin{array}{l}\text { N=30. Median } \\
\text { of } 542 \text { days } \\
\text { (IQR } 175 \text { to } \\
961 \text { days) }\end{array}$ & $\begin{array}{l}\text { All-cause mortality; } \\
\text { MACE (BVS } \\
\text { thrombosis, } \\
\text { symptom-driven } \\
\text { TLR, non-fatal target } \\
\text { vessel MI, TVR), and } \\
\text { cardiac death }\end{array}$ & None \\
\hline 7. & $\begin{array}{l}\text { Vaquerizo et } \\
\text { al. [17] }\end{array}$ & 2016 & $\begin{array}{l}\text { Prospective } \\
\text { single-arm } \\
\text { registry } \\
\text { (ABSORB- } \\
\text { CTO pilot) }\end{array}$ & $\begin{array}{l}\mathrm{N}=33 \text {. Twelve } \\
\text { months follow- } \\
\text { up }\end{array}$ & $\begin{array}{l}\text { Device patency } \\
\text { assessed by various } \\
\text { modalities of imaging }\end{array}$ & None \\
\hline 8. & $\begin{array}{l}\text { Özel et al. } \\
{[18]}\end{array}$ & 2016 & $\begin{array}{l}\text { Prospective } \\
\text { single-center } \\
\text { single-arm } \\
\text { study }\end{array}$ & $\begin{array}{l}\mathrm{N}=41 \text {. Twelve } \\
\text { months follow- } \\
\text { up }\end{array}$ & $\begin{array}{l}\text { TLR, TVR, rates of } \\
\text { MI, angina, CABG, } \\
\text { and rates of death }\end{array}$ & None \\
\hline 9. & $\begin{array}{l}\text { Lesiak et al. } \\
\text { [19] }\end{array}$ & 2016 & $\begin{array}{l}\text { Prospective } \\
\text { non- } \\
\text { randomized } \\
\text { clinical pilot } \\
\text { registry }\end{array}$ & $\begin{array}{l}\mathrm{N}=40 . \text { Median } \\
556 \text { days ( } 274 \\
\text { to } 932 \text { days; } \\
\text { IQR } 374 \text { to } 706 \\
\text { days) }\end{array}$ & $\begin{array}{l}\text { TVF is described as } \\
\text { the mixture of } \\
\text { clinically driven } \\
\text { TVR, target vessel } \\
\text { MI, or cardiac death. } \\
\text { Device success } \\
\text { (successful } \\
\text { deployment at }\end{array}$ & $\begin{array}{l}\text { Scaffold thrombosis } \\
\text { incidence }\end{array}$ \\
\hline
\end{tabular}




\begin{tabular}{|c|c|c|c|c|c|c|}
\hline & & & & & $\begin{array}{l}\text { intended area), and } \\
\text { procedure success } \\
\text { rate (TIMI flow grade } \\
3 \text {, residual stenosis } \\
<30 \% \text { without major } \\
\text { procedural } \\
\text { complications) }\end{array}$ & \\
\hline 10 & $\begin{array}{l}\text { Azzalini et } \\
\text { al. [20] }\end{array}$ & 2016 & $\begin{array}{l}\text { Retrospective } \\
\text { multi-center } \\
\text { registry }\end{array}$ & $\begin{array}{l}\text { BVS group } \\
\text { (n=153) } \\
\text { compared t0 } \\
\text { DES group } \\
(\mathrm{n}=384) . \\
\text { Median of } 703 \\
\text { days (IQR } 426 \\
\text { to } 989 \text { days) }\end{array}$ & $\begin{array}{l}\text { TVF incidence is } \\
\text { described as the } \\
\text { combination of } \\
\text { ischemia-driven } \\
\text { TLR, target-vessel } \\
\text { myocardial } \\
\text { infarction, and } \\
\text { cardiac death }\end{array}$ & None \\
\hline 11. & $\begin{array}{l}\text { Ojeda et al. } \\
\text { [21] }\end{array}$ & 2015 & $\begin{array}{l}\text { Single-center } \\
\text { observational } \\
\text { study }\end{array}$ & $\begin{array}{l}\mathrm{N}=42 . \text { Mean of } \\
13 \pm 5 \text { months, } \\
\text { median of } 12 \\
\text { (IQR } 9.75 \text { to } \\
16) \text { months }\end{array}$ & $\begin{array}{l}\text { Technical success is } \\
\text { described as TIMI } \\
\text { flow grade } 3 \text { and } \\
\text { patent vessel having } \\
<30 \% \text { residual } \\
\text { stenosis achieved. } \\
\text { MACE is described } \\
\text { as a mixture of TLR, } \\
\text { MI, and cardiac } \\
\text { death, Scaffold } \\
\text { thrombosis. } \\
\text { Periprocedural MI. }\end{array}$ & None \\
\hline 12. & $\begin{array}{l}\text { Goktekin et } \\
\text { al. [22] }\end{array}$ & 2015 & $\begin{array}{l}\text { Multi-center } \\
\text { registry }\end{array}$ & $\begin{array}{l}\mathrm{N}=70 . \text { Median } \\
\text { of } 11 \text { (IQR } 7 \text { to } \\
\text { 18) months }\end{array}$ & $\begin{array}{l}\text { Compound of non- } \\
\text { fatal MI and all-cause } \\
\text { death. A combination } \\
\text { of safety outcomes of }\end{array}$ & None \\
\hline
\end{tabular}


MACE, including

symptom-driven

TLR, MI, and death

13. Wiebe et al. 2014 Observational $\mathrm{N}=23$. Median Procedural success is None

[23]

study

of 108 (79.5 to described as

214.5 days) estimated residual

stenosis of $\leq 30 \%$ on

angiography and

optical coherence

tomography, and

successful

deployment of the

scaffold at target

area. MACE is

described as MI,

unscheduled

percutaneous and

surgical target lesion,

and cardiac death.

TVF included

percutaneous or

surgical TVR, target

vessel MI, and

cardiac death.

Note: $\mathrm{CTO}=$ chronic total occlusion; IQR $=$ Interquartile range; MACE $=$ Major adverse cardiovascular event; TLR = Target lesion revascularization; $\mathrm{MI}=$ Myocardial infarction; TVF $=$ Target vessel failure; TVR $=$ Target vessel revascularization; BVS $=$ Bioresorbable vascular scaffolds; DES = Drug-eluting stents; MSCT = Multi-slice computer tomography $;$ CABG = Coronary artery bypass grafting; TIMI = Thrombolysis in myocardial infarction.

\section{Single-Arm Studies}

Eleven single-arm investigations were selected, most of which were small retrospective and prospective studies [6, 12-14, 16-19, 21-23]. Clinical and demographic features were alike in all investigations as do with their published end results. 
The median duration of follow-up in this population ranged from 108 days to 556 days. A combination of target lesion revascularization, target vessel MI, and cardiac death was published in five investigations, resulting in $2.64 \%$ (95\% CI: $1.04 \%$ to $4.24 \%$ ). Yamaç et al. conducted an investigation which recorded one cardiac death (3 percent of their samples) throughout the period of follow-up [16]. However, only Maeremans et al. recorded one noncardiac mortality (2.4\% of their samples) [14]. The non-fatal myocardial infarction incidence was reported to be $1.07 \%$ (95\% CI: $0.09 \%$ to $2.06 \%$ ). Target lesion revascularization incidence was reported to be $2.51 \%$ (95\% CI: $0.86 \%$ to $4.16 \%$ ). The greatest rate of target lesion revascularization was $8.6 \%$ as recorded by Yamaç et al. [16]. The scaffold or stent thrombosis incidence was reported to be $1.3 \%$ (95\% CI: $-0.09 \%$ to $2.39 \%$ ). The combined restenosis rate, as reported in six investigations, was $4.45 \%$ (95\% CI: $2.04 \%$ to $6.86 \%$ ). Using the primary tool of ROBINS-I to evaluate the non-randomized investigations, each paper went through a detailed assessment of possible biases. Considering that a minimum of one evaluated areas of every investigation was concluded to possess a risk for critical bias, the tool revealed that twelve investigations had an overall risk for critical bias. The report by Azzalini et al. was assessed to possess a severe bias risk.

\section{Double-Arm Studies}

Two double-arm investigations were selected, comparing DES with BVS in detailed evidence of follow-up as seen in Table 2. The bigger investigation was conducted by Azzalini et al. in a multi-center retrospective registry, involving 537 subjects [20]. The study juxtaposed the end results of patients ( $n=153)$ who were implanted with the first-generation Absorb BVS and compared them to another group $(n=384)$ who were treated with second-generation DES.

The primary outcome was a target vessel failure (TVF), being described as the combination of ischemia-driven TLR, target vessel myocardial infarction, and cardiac death. The median duration of follow-up was 703 days with IQR of 426 days to 989 days. There were no notable differences in events rates among the two groups.

The individual comparison of the primary outcome is as follows: TVF (4.6\% in BVS versus $7.7 \%$ in DES; HR: $0.59,95 \% \mathrm{CI}: 0.26$ to $1.35 ; \mathrm{p}=0.21)$, ischemia-driven TLR $(4.0 \%$ in BVS versus $4.1 \%$ in DES; HR: 0.95 ; $95 \%$ CI: 0.37 to 2.45 ; $=0.92$ ), and stent or scaffold thrombosis $(0.6 \%$ in BVS versus $0.7 \%$ in DES, $\mathrm{p}=0.86)$. Different inverse probability by Cox regression analysis with intervention weight-adjustment failed to confirm any notable differences in outcomes among the individuals. Nevertheless, when clinical, procedural, and angiographic variables were affixed altogether to the model, the calculation revealed an insignificant rise in TVF and ischemia-driven TLR risks in the BVS population (adjusted HR 
of $3.45 ; 95 \%$ CI: 0.87 to $13.66 ; \mathrm{p}=0.08$ ). Kugler et al. executed a different double-arm observational study [15] using a modest prospective registry, including 29 samples, and 14 of whom had been implanted with BVS and 15 of whom underwent DES. A clinical follow-up of 12 months period displayed outcomes alike to those published by Azzalini et al. The study did not exhibit any outcomes differences within BVS and DES populations. TVF and ischemiadriven TLR risks, as well as the thrombosis occurrence of the scaffold, were equivalent within two populations.

Table 2. Bias risk assessment in selected studies using Cochrane ROBINS-I

\begin{tabular}{|c|c|c|c|c|c|c|c|c|}
\hline Author & $\begin{array}{c}\text { Confoun } \\
\text { ding } \\
\text { Bias }\end{array}$ & $\begin{array}{c}\text { Participant } \\
\text { Selection } \\
\text { Bias }\end{array}$ & $\begin{array}{c}\text { Inter- } \\
\text { ventions } \\
\text { Classi- } \\
\text { fication } \\
\text { Bias }\end{array}$ & $\begin{array}{c}\text { Intended } \\
\text { Inter- } \\
\text { vention } \\
\text { Deviation } \\
\text { Bias }\end{array}$ & $\begin{array}{c}\text { Missing } \\
\text { Data Bias }\end{array}$ & $\begin{array}{c}\text { Out- } \\
\text { comes } \\
\text { Measure } \\
\text {-ment } \\
\text { Bias }\end{array}$ & $\begin{array}{c}\text { Repor- } \\
\text { ted } \\
\text { Results } \\
\text { Bias }\end{array}$ & $\begin{array}{c}\text { Overall } \\
\text { Bias }\end{array}$ \\
\hline $\begin{array}{l}\text { La Manna et } \\
\text { al. [12] }\end{array}$ & Critical & Critical & Serious & Moderate & Serious & Critical & Moderate & Critical \\
\hline $\begin{array}{l}\text { Mitomo et } \\
\text { al. [13] }\end{array}$ & Critical & Serious & Critical & Moderate & Critical & Critical & Moderate & Critical \\
\hline $\begin{array}{l}\text { Maeremans } \\
\text { et al. [14] }\end{array}$ & Critical & Critical & Serious & Moderate & Serious & Critical & Moderate & Critical \\
\hline $\begin{array}{l}\text { Kugler et } \\
\text { al. [15] }\end{array}$ & Critical & Serious & Critical & Moderate & Critical & Critical & Moderate & Critical \\
\hline $\begin{array}{l}\text { Fam et } \\
\text { al. [6] }\end{array}$ & Critical & Critical & Serious & Moderate & Moderate & Critical & Moderate & Critical \\
\hline $\begin{array}{l}\text { Yamaç et } \\
\text { al. [16] }\end{array}$ & Critical & Critical & Serious & Moderate & Moderate & Critical & Moderate & Critical \\
\hline $\begin{array}{l}\text { Vaquerizo } \\
\text { et al. [17] }\end{array}$ & Critical & Critical & Serious & Moderate & Moderate & Critical & Moderate & Critical \\
\hline $\begin{array}{l}\text { Özel et } \\
\text { al. [18] }\end{array}$ & Critical & Critical & Serious & Moderate & Moderate & Critical & Moderate & Critical \\
\hline $\begin{array}{l}\text { Lesiak et } \\
\text { al. [19] }\end{array}$ & Critical & Critical & Serious & Moderate & Moderate & Critical & Moderate & Critical \\
\hline $\begin{array}{l}\text { Azzalini et } \\
\text { al. [20] }\end{array}$ & Serious & Serious & Serious & Moderate & Moderate & Serious & Moderate & Serious \\
\hline
\end{tabular}




\begin{tabular}{lllllllll}
\hline $\begin{array}{l}\text { Ojeda et } \\
\text { al. [21] }\end{array}$ & Critical & Critical & Serious & Moderate & Moderate & Critical & Moderate & Critical \\
\hline $\begin{array}{l}\text { Goktekin et } \\
\text { al. }[22]\end{array}$ & Critical & Critical & Serious & Moderate & Moderate & Critical & Moderate & Critical \\
\hline Wiebe et & Critical & Critical & Serious & Moderate & Moderate & Critical & Moderate & Critical \\
al. [23] & & & & & & & & \\
\end{tabular}

\section{DISCUSSION}

DES still leads as the preferred device for percutaneous coronary interventions, however, BVS was invented as a substitute to DES. The theoretical benefit of BVS lies on full resorption of scaffolds or stents after two years of implantation with the resultant vasomotion rehabilitation. This condition avoids the potential "caged vessel" complication which eventually leads to delayed thrombosis of the stent $[9,10]$. Theoretically, those features should be favorable for the revascularization procedures of CTO where an extended length of scaffold segment is frequently necessitated. Nonetheless, these favorable features would require confirmation in clinical trials before being approved for comprehensive technology use. This review collected 13 investigations of generally moderate evidence. The analysis of selected papers exhibited promising outcomes for the implantation of BVS in CTO population. The majority of the investigations exhibited a relatively small incidence of combination and individual outcomes after a reasonable period of follow-up.

Azzalini et al. executed a comprehensive double-arm investigation which carried out the unadjusted analysis and the primary adjusted analysis. They did not exhibit any statistically significant difference in the long-term results within the BVS and DES population. However, the investigation revealed an inclination to a greater adjusted risk in the BVS group for ischemia-driven target lesion failure than the DES group [20]. Despite showing moderatequality evidence in CTO, three new trials have pointed out a heightened stent thrombosis risk in comparison with DES in PCI [24-26]. The differences of conclusions from selected RCTs could be attributed to variable hemodynamics in CTO stenting, selection of patients, inadequate follow-up, and variations in reporting in this review.

This inclination could be described by distinguishing the first-generation BVS with second-generation DES, since the latter is equipped with finer struts and therefore generating lower blood flow turbulence in addition to less thrombosis restenosis risk [27]. As a consequence of flow disturbances, concerns about rising cases of scaffold thrombosis (ST) 
were brought up and were also confirmed by multiple trials and meta-analysis. Those investigations revealed a heightened scaffold thrombosis incidence in comparison to DES [2426]. However, this review did not show any distinction in the rate of thrombosis between BVS and DES groups in CTO patients. Additionally, in single-arm observational investigations, the incidence of thrombosis was found to be faint. This finding could be associated with inadequate sample size. It can also be explained by careful selection of lesion for intervention to avoid small vessels with a lower velocity of blood flow and more skillful operators who are exposed to the lesions' complexity using supplementary imaging modalities, such as optical coherence tomography or intravascular ultrasound. Finally, recent concerns should also be examined, especially related to the possible subclinical complication of restenosis in CTO lesion and also stent or scaffold thrombosis [20].

Angiographic follow-up is essential for the aforementioned reason to reveal the accurate incidence rates of scaffold thrombosis and restenosis. In this review, eight investigations conducted a concrete non-invasive or invasive angiographic follow-up after the implantation of BVS. However, in most investigations, this imaging method was performed not in all patients, making the accurate rates of scaffold thrombosis or restenosis to be underestimated. For example, Mitomo et al. in 2017 reported that only as much as $33.8 \%$ of patients went through the angiographic follow-up [13] while in 2018, Maeremans et al. recorded approximately $83 \%$ of patients went through the multi-slice computed tomography angiographic follow-up [14]. Despite encouraging findings, the first-generation BVS was withdrawn from the guideline for clinical practice in an account of the safety alert issued by Food and Drug Administration to Absorb BVS (Abbott) device owing to its confirmed heightened rates for ST [28]. The next-generation BVS, with enhanced flow parameters and finer struts, is recently undergoing research with promising preliminary outcomes [29]. Simultaneously, published evidence on the effectiveness of second-generation stents or scaffolds for CTO are currently absent.

\section{LIMITATIONS}

This review has multiple constraints. First, involved investigations were observational in design, and published RCTs are absent to date. This condition makes the available evidence prone to possible biases, such as confounding and selection biases. The existence of such biases was considered to be of inferior quality in this review. Second, given a notable heterogeneity in studies involved, a meta-analysis could not be executed. Therefore, a systematic review is preferred. Third, the median duration of follow-up for most of the studies was shorter than two 
years, putting hindrances on the capacity to evaluate the theoretical benefits of BVS after the scaffold or stent resorption. Fourth, involved investigations studied only the first-generation BVS Absorb, which possess unflattering flow characteristics.

\section{CONCLUSIONS}

The evidence studying the application of the first-generation BVS in CTO patients is not many in number and restricted by inadequate sample in observational studies. Currently, the available evidence is optimistic and implies satisfactory outcomes as compared to the second-generation DES. Additional research and investigation by means of randomized clinical trials and the employment of newer, more superiorly-designed generation of stents and scaffolds is necessitated to control confounders and to determine the existence of a significant distinction among these devices.

\section{DISCLOSURE}

\section{Funding}

None.

\section{Conflict of Interest}

The author declares there is no conflict of interest regarding all aspect of the study.

\section{Author Contribution}

PHW is responsible for the study from the search of papers and articles, data gathering, data analysis, until reporting the results of the review.

\section{REFERENCES}

1. Di Mario C, Werner GS, Sianos G, et al.: European perspective in the recanalisation of Chronic Total Occlusions (CTO): consensus document from the EuroCTO Club. EuroIntervention. 2007, 3:30-43.

2. Fefer P, Knudtson ML, Cheema AN, et al.: Current perspectives on coronary chronic total occlusions: the Canadian Multicenter Chronic Total Occlusions Registry. J Am Coll Cardiol. 2012, 59:991-997. 10.1016/j.jacc.2011.12.007

3. Christakopoulos GE, Christopoulos G, Carlino M, et al.: Meta-analysis of clinical outcomes of patients who underwent percutaneous coronary interventions for chronic total occlusions. Am J Cardiol. 2015, 115:1367-1375. 10.1016/j.amjcard.2015.02.038 
4. Chung C-M, Nakamura S, Tanaka K, et al.: Effect of recanalization of chronic total occlusions on global and regional left ventricular function in patients with or without previous myocardial infarction. Catheter Cardiovasc Interv. 2003, 60:368374. $10.1002 / \mathrm{ccd} .10641$

5. Jang WJ, Yang JH, Choi S-H, et al.: Long-term survival benefit of revascularization compared with medical therapy in patients with coronary chronic total occlusion and welldeveloped collateral circulation. JACC Cardiovasc Interv. 2015, 8:271279. 10.1016/j.jcin.2014.10.010

6. Fam JM, Ojeda S, Garbo R, et al.: Everolimus-eluting bioresorbable vascular scaffolds for treatment of complex chronic total occlusions. EuroIntervention. 2017, 13:355363. 10.4244/EIJ-D-16-00253

7. Suh J, Park D-W, Lee J-Y, et al.: The relationship and threshold of stent length with regard to risk of stent thrombosis after drug-eluting stent implantation. JACC Cardiovasc Interv. 2010, 3:383-389. 10.1016/j.jcin.2009.10.033

8. Shirai S, Kimura T, Nobuyoshi M, et al.: Impact of multiple and long sirolimus-eluting stent implantation on 3-year clinical outcomes in the j-Cypher Registry. JACC Cardiovasc Interv. 2010, 3:180-188. 10.1016/j.jcin.2009.11.009

9. Serruys PW, Ormiston JA, Onuma Y, et al.: A bioabsorbable everolimus-eluting coronary stent system (ABSORB): 2-year outcomes and results from multiple imaging methods. Lancet. 2009, 373:897-910. 10.1016/S0140-6736(09)60325-1

10. Serruys PW, Ormiston J, Van Geuns R-J, et al.: A polylactide bioresorbable scaffold eluting everolimus for treatment of coronary stenosis: 5-year follow-up. J Am Coll Cardiol. 2016, 67:766-776. 10.1016/j.jacc.2015.11.060

11. Liberati A, Altman DG, Tetzlaff J, et al.: The PRISMA statement for reporting systematic reviews and meta-analyses of studies that evaluate health care interventions: explanation and elaboration. J Clin Epidemiol. 2009, 62:1-34. 10.1016/j.jclinepi.2009.06.006

12. La Manna A, Miccichè E, D'Agosta G, et al.: Vascular response and healing profile of everolimus-eluting bioresorbable vascular scaffolds for percutaneous treatment of chronic total coronary occlusions: a one-year optical coherence tomography analysis from the GHOST-CTO registry. Int J Cardiol. 2018, 253:45-49. 10.1016/j.ijcard.2017.10.107

13. Mitomo S, Naganuma T, Fujino Y, et al.: Bioresorbable vascular scaffolds for the treatment of chronic total occlusions: an international multicenter registry. Circ Cardiovasc Interv. 2017, 10:e004265. 10.1161/CIRCINTERVENTIONS.116.004265 
14. Maeremans J, Verhaert D, Pereira B, et al.: One-year clinical and computed tomography follow-up after implantation of bioresorbable vascular scaffolds in patients with coronary chronic total occlusions. Catheter Cardiovasc Interv. 2018, 92:488496. $10.1002 / \mathrm{ccd} .27390$

15. Kugler C, Marovic S, Rottbauer W, Wöhrle J: Bioresorbable scaffolds compared with everolimus-eluting stents for the treatment of chronic coronary total occlusion: clinical and angiographic results of a matched paired comparison. Coronary Artery Disease. 2017, 28:120-125. 10.1097/MCA.0000000000000449

16. Yamac AH, Yildiz A, Nasifov M, Tastan A, Bashirov N, Goktekin O: Clinical and angiographic outcomes at more than 1 year after treatment of chronic total occlusions with the everolimus-eluting bioresorbable vascular scaffold. Turk Kardiyol Dern Ars. 2016, 44:647-655. 10.5543/tkda.2016.21774

17. Vaquerizo B, Barros A, Pujadas S, et al.: One-year results of bioresorbable vascular scaffolds for coronary chronic total occlusions. Am J Cardiol. 2016, 117:906917. 10.1016/j.amjcard.2015.12.025

18. Özel E, Taştan A, Öztürk A, Özcan EE, Kilicaslan B, Özdogan O: Procedural and oneyear clinical outcomes of bioresorbable vascular scaffolds for the treatment of chronic total occlusions: a single-centre experience. Cardiovasc $J$ Afr. 2016, 27:345349. 10.5830/CVJA-2016-033

19. Lesiak M, Lanocha M, Araszkiewicz A, et al.: Percutaneous coronary intervention for chronic total occlusion of the coronary artery with the implantation of bioresorbable everolimus-eluting scaffolds. Poznan CTO-Absorb Pilot Registry. EuroIntervention. 2016, 12:144-151. 10.4244/EIJV12I2A27

20. Azzalini L, Giustino G, Ojeda S, et al.: Procedural and long-term outcomes of bioresorbable scaffolds versus drug-eluting stents in chronic total occlusions: the BONITO registry (bioresorbable scaffolds versus drug-eluting stents in chronic total occlusions). Circ Cardiovasc Interv. 2016, 9:e004284. 10.1161/CIRCINTERVENTIONS.116.004284

21. Ojeda S, Pan M, Romero M, et al.: Outcomes and computed tomography scan follow-up of bioresorbable vascular scaffold for the percutaneous treatment of chronic total coronary artery occlusion. Am J Cardiol. 2015, 115:1487-1493. 10.1016/j.amjcard.2015.02.048

22. Goktekin O, Yamac AH, Latib A, et al.: Evaluation of the safety of everolimus-eluting bioresorbable vascular scaffold (BVS) implantation in patients with chronic total coronary occlusions: acute procedural and short-term clinical results. J Invasive Cardiol. 2015, 27:461-466. 
23. Wiebe J, Liebetrau C, Dörr O, et al.: Feasibility of everolimus-eluting bioresorbable vascular scaffolds in patients with chronic total occlusion. Int J Cardiol. 2015, 179:9094. 10.1016/j.ijcard.2014.10.032

24. Serruys PW, Chevalier B, Sotomi Y, et al.: Comparison of an everolimus-eluting bioresorbable scaffold with an everolimus-eluting metallic stent for the treatment of coronary artery stenosis (ABSORB II): a 3 year, randomised, controlled, single-blind, multicentre clinical trial. Lancet. 2016, 388:2479-2491. 10.1016/S0140-6736(16)32050-5

25. Wykrzykowska JJ, Kraak RP, Hofma SH, et al.: Bioresorbable scaffolds versus metallic stents in routine PCI. N Engl J Med. 2017, 376:2319-2328. 10.1056/NEJMoa1614954

26. Cassese S, Byrne RA, Ndrepepa G, et al.: Everolimus-eluting bioresorbable vascular scaffolds versus everolimus-eluting metallic stents: a meta-analysis of randomised controlled trials. Lancet. 2016, 387:537-544. 10.1016/S0140-6736(15)00979-4

27. Pache J, Kastrati A, Mehilli J, et al.: Intracoronary stenting and angiographic results: strut thickness effect on restenosis outcome (ISAR-STEREO-2) trial. J Am Coll Cardiol. 2003, 41:1283-1288. 10.1016/S0735-1097(03)00119-0

28. UPDATE on increased rate of major adverse cardiac events observed in patients receiving Abbott Vascular's Absorb GT1 bioresorbable vascular scaffold (BVS) - Letter to health care providers. (2017). Accessed: February 15, 2018: https://www.fda.gov/MedicalDevices/Safety/LetterstoHealthCareProviders/ucm58 2728.htm.

29. FUTURE-I: six-month clinical, angiographic IVUS, and OCT results with a thin-strut PLLA-based sirolimus-eluting bioresorbable vascular scaffold in patients with coronary artery disease. (2016). Accessed: March 04, 2018: https://www.tctmd.com/videos/futureisixmonth-clinical-angiographic-ivus-and-oct-results-with-a-thinstrut-pllabased-s.... 